\title{
The influence of mayors as candidates in the 2017 parliamentary elections on voter decision-making in Czechia
}

\section{Radek Pileček*}

Charles University, Faculty of Science, Department of Social Geography and Regional Development, Czechia

* Corresponding author: radek.pilecek@natur.cuni.cz

\begin{abstract}
Local activities of electoral candidates represent one of the key factors influencing voting behaviour. Many studies have shown an elevated electoral support for candidates in the municipality of their residence and the surrounding region. By using the example of mayors who candidated in the 2017 Czech parliamentary elections, this article proves that this voting behaviour is manifested not only through the territorial concentration of preferential votes, but also through higher local electoral support of political parties represented by these candidates. This so-called friends and neighbours effect is stronger in smaller, less populous municipalities. Its spatial extent is not necessarily limited to the respective municipality, but if a well-known and popular mayor appears at the top of the regional candidate list, it can affect voters living many kilometers away, especially in non-metropolitan areas.
\end{abstract}

\section{KEYWORDS}

electoral geography; friends and neighbours effect; voting behaviour; parliamentary elections; residuals; Czechia

Received: 17 August 2021

Accepted: 10 October 2021

Published online: 19 November 2021

Pileček, R. (2021): The influence of mayors as candidates in the 2017 parliamentary elections on voter decision-making in Czechia. AUC Geographica 56(2), 234-247 https://doi.org/10.14712/23361980.2021.15

(C) 2021 The Authors. This is an open-access article distributed under the terms of the Creative Commons Attribution License (http://creativecommons.org/licenses/by/4.0). 


\section{Introduction}

In recent years, (not only) the Czech political scene has undergone significant changes. This is especially the rise of populism and the political parties that operate on its principles (Mudde and Kaltwasser 2018), dividing society through controversial topics such as the perception of international migration or the attitudes towards the European Union (Inglehart and Norris 2016). The traditional division of Czech political parties on the right-wing and left-wing has gradually turned into a duel between populism on the one hand and entities holding the principles of liberal democracy on the other, which has substantially redrawn the current Czech electoral maps and disrupted the long-term continuity of electoral patterns. What remains, however, is certainly a large number of voters, for whose decision on which political party to support in the elections, specific candidates - popular national and also local personalities of the political party - are more important than its ideology (Mikešová 2019).

The main goal of the conducted research is to empirically contribute to the understanding of spatial patterns of electoral support of political parties in Czechia, specifically on the example of the Czech parliamentary elections 2017. The study focuses predominantly on the impact of spatial context on voter decision-making, namely on the friends and neighbours effect, which is a term for the influence of geographical distance between voter and candidate (Arzheimer and Evans 2012). We can often observe that candidates receive higher electoral support in their municipality of residence and the surrounding area (Gimpel et al. 2008; Malcová 2012; Roy and Alcantara 2015). Not all candidates have this ability, but especially those who are familiar to local citizens and strongly connected with a specific municipality or locality, such as mayors, can mobilize their "home" voters. Alongside doctors or teachers, mayors are those whom citizens trust very much (Sedláčková 2012), which is important for deciding on the support of a particular candidate (and indirectly the party he or she is running for) in elections.

In the Czech parliamentary elections 2017, mayors were one of the most frequently represented professions on candidate lists (Dýnková 2017). This contribution analyses not only their spatial distribution, but mainly their potential to modify the voting behaviour of the inhabitants of the respective municipalities. In some cases, the influence of their candidacy may be noticeable in larger areas (Bernard, Kostelecký, and Šimon 2014; Panagopoulos and Bailey 2020). In this study, it is monitored using spatial statistical tools of geoinformation systems on the example of STAN candidates, a political movement whose full name is Mayors and Independents and which is primarily based on the personalities that people know from communal politics. This is the main reason why STAN was chosen as the primary object of the study.

\section{Theoretical background}

The support of political parties in Czechia and also in other countries is certainly not spatially homogeneous, as evidenced by territorial differences in election results. These differentiations can be explained by two approaches in the field of electoral geography. The first is a compositional approach for which individual characteristics of voters, such as gender, age, education, religion, standard of living or type of employment, are key factors in the question of the formation of different political orientations (Kitschelt 1994). The second is a contextual approach that emphasizes the influence of the local environment, where we live and which contributes to the formation of our values and opinions, including voting behaviour (Cox 1969; Kostelecký and Čermák 2004). The application of these two approaches is not exclusive; on the contrary, it is always ideal to combine both (Bernard and Kostelecký 2014; Weng 2015).

Most electoral-geographical studies are based on the search for a relationship between the composition of the population of territorial-administrative units and the electoral support of specific political parties. Differences in the socio-demographic and socio-economic structure between the analysed geographical units significantly determine local and regional differences in election results (Kowalski 1999; Kostelecký 2009; Harbers 2017; Lepič 2017). This idea is based on the cleavage theory (Lipset and Rokkan 1967). The premise of this theory is the fact that people belonging to the same social group show identical or at least similar voting behaviour and that they are spatially concentrated in certain areas - for example historically in Western Europe there were conservative-minded villagers working mainly in agriculture and, on the other hand, much more liberal-oriented inhabitants of port cities. However, Hloušek (2002) shows in his study that the adoption of Lipset's and Rokkan's cleavage theory does not lead to a deeper understanding of the development of national party systems during the 1990s in Central and Eastern Europe, including Czechia. According to Hloušek (2002), it is necessary to work with a different matrix of variables in the analysis of regional differences in election results than those applied by older research from the Western European electoral environment.

\subsection{Spatial context of electoral behaviour}

Only a minority of research in the field of electoral geography pays dominant attention to the influences of the spatial context (Weng 2015). Contextual factors influencing electoral behaviour can have an impact at different subnational levels, with different strength, and also in very diverse forms (Taylor and Johnston 1979). Agnew (1996) points out that the context is always multi-scale, from household and close neighbourhood to the context of the local and regional environment, as well as spatio-temporal, because it 
changes significantly over time. Specific historical events also influence voting behaviour in a certain locality and their impact can be sometimes seen even for several generations - for example, in Czechia, demographic development in the Sudetenland after the Second World War associated with disruption of local communities and settlement continuity, which results in an overall lower level of civil society, including civic engagement, and consequently regularly lower voter turnout (Šimon 2015).

One of the most frequently discussed contextual factors of electoral behaviour is the neighbourhood effect: The influence of personal interactions between people, as the voter decision-making is highly conditioned by opinions of people around them (Pattie and Johnston 2000). The neighbourhood effect is best described by the phrase "people who talk together, vote together" (Miller 1977: 65). People partly take opinions, including who to support in the elections, from their relatives and close friends and are influenced by information circulating in their social networks. Traditionally, this term was used mainly for the influence of family, friends or colleagues at work, but in today's modern age, these social networks can also be understood as internet communities and "personal" interactions between people in the virtual world.

A large questionnaire survey on the parliamentary elections in Great Britain found that people are more likely to change their vote in a certain direction if those with whom they most discuss political issues also support it (Pattie and Johnston 2000). Within the contextual approach of electoral geography, the neighborhood effect can be understand as strengthening the importance of individual socio-demographic and socio-economic characteristics of voters in case of their agreement with people around them, or weakening of their importance in a situation where the voter is mainly in contact with people from different social groups and with different political opinions (Butler and Stokes 1969; Stephens 1981; MacAllister et al. 2001).

Other factors of the spatial context that significantly modify electoral behaviour in specific localities are the effects of the spatial organization of political parties (Shin 2001). This is particularly the importance of locally targeted election campaigns - campaign effect, but also the territorial distribution of strong candidates who have the potential to gain above-average electoral support in their hometowns and regions not only for themselves but also for the political party they represent. For the second described phenomenon, some authors use the term friends and neighbours effect (Tatalovich 1975; Johnston et al. 2016; Panagopoulos and Bailey 2020), while others prefer the term candidate effect (Roy and Alcantara 2015).

In fact, both effects connected with the parties' regional activities are very often interrelated (Pickery 2002). If the political party has strong personalities at the top of candidate list in a certain locality, it allows it to intensify the election campaign here, which further attracts new voters. Empirical research on the campaign effect (Denver and Hands 1993; Johnston and Pattie 1997) show not only a significantly higher electoral support of a political party in localities where it spents more finances during the election campaign, but also an apparent mobilization of voters, which is reflected in higher overall voter turnout in these areas. According to these studies, the campaign effect is not primarily about the conversion of voters of other parties and movements, but rather about the mobilization of politically ambivalent citizens who would probably not even go to the polls without the influence of the election campaign.

The potential of voter mobilization is also shown by the friends and neighbours effect (Rice and Macht 1987; Baumann et al. 2021). The causes of this effect are not only the possible personal relations between the candidate and voters from the same municipality or locality, but also the so-called "shared geography" and local patriotism play a key role, attracting citizens to ballot boxes to support their local candidate (Panagopoulos, Leighley, and Hamel 2017). The primary reason for the existence of the friends and neighbours effect can be conceptualized as a relationship between trust and distance. People have more trust in someone, who is close to them, not only in friendly and emotional way, but also geographically (Gimpel et al. 2008). With increasing distance between people, trust decreases, as does the electoral support of the candidate (Górecki and Marsh 2012; Malcová 2012).

In the Czech parliamentary elections, the friends and neighbours effect has two main impacts. It manifests itself in the spatial concentration of preferential votes of individual candidates near their place of residence (Voda and Pink 2009), but secondarily also in the higher electoral support of political parties in localities where some of their strong leading candidates stand (Bernard, Kostelecký, and Šimon 2014). The analytical focus of this article is on the relevance of the friends and neighbours effect in relation to the choice of the supported political party, not to the preferential voting for individual candidates.

When monitoring the influence of the effect on the spatial patterns of preferential voting, we must keep in mind that the position on the candidate list plays a big role. In the Czech electoral environment, candidates at the top of the candidate lists have a noticeable advantage, a greater chance of being elected, which is associated with a larger share of preferential votes received. The whole concept (relationship between preferential voting and candidates' places of residence) is therefore better observable, for example, in Finland (Put, Schoultz, and Isotalo 2020), where candidates are listed in alphabetical order.

Recent studies of the influence of local candidates on the choice of supported political party show that the effect is stronger within the majority, especially FPTP (first past the post), electoral systems (Kal 
Munis 2021; Put 2021) and that the degree of regional identity of the local population is very important. The friends and neighbours effect can be a reflection of the local identity of voters, their sense of belonging to their municipality or region, for which they prefer candidates from their immediate surroundings (Schulte-Cloos and Bauer 2021).

New research tends to be linked to practice and can serve to optimize the process of drawing up candidate lists and as a basis for the nomination strategies of individual political parties and movements (Put, Schoultz, and Isotalo 2020). The use of similar research by political parties is supported by growing tendencies to personalise politics. In connection with this fact, an increasing share of voters focuses more on the selection of candidates than on the parties and tends to favor those who act more credibly for them. It can be sympathy for the party's election leader or the support of particular locally connected candidates from the same municipality or nearby town, such as mayors, whose influence on voter decision-making is the core theme of this paper.

No similarly focused academic work has been published in Czechia so far. Nevertheless, Mikešová (2019) mentioned the importance of mayors as candidates in the Czech parliamentary elections, when she analysed electoral behaviour in different regions of the country through in-depth interviews. Some respondents stated that the high quality management of their municipality by a certain political party could be the reason to support the same party also at a higher political level. Studies directly aimed at the advantage of being a mayor when running for national parliament can be found in foreign literature (Blais et al. 2003; Put and Maddens 2015). However, these authors used very different approaches to measure the relevance and strength of the friends and neighbours effect, so the findings are not comparable with the results of my research.

\section{Methodology and data}

In the Czech parliamentary elections 2017, more than five million valid votes were cast with a turnout of $60.8 \%$. The dominant winner of the elections in all regions of Czechia was the political movement ANO 2011 (ANO) with an overall electoral support of 29.6\%. In order to win seats in the Chamber of Deputies, it is necessary to exceed the $5 \%$ electoral gain limit, which was achieved also by eight other political parties: Civic Democratic Party (ODS), Czech Pirate Party (Piráti), Freedom and Direct Democracy (SPD), Communist Party of Bohemia and Moravia (KSČM), Czech Social Democratic Party (ČSSD), Christian and Democratic Union - Czechoslovak People's Party (KDU-ČSL), TOP 09, Mayors and Independents (STAN).

In the first step of the analysis, this paper observes the dependence of electoral support of all nine successful political parties (and movements) on the territorially heterogeneous structure of the population at the level of municipalities. The nine separate multiple linear regression models always included one dependent variable, which was the electoral support of the analysed political party, and six independent variables (predictors), representing both socio-demographic (age, education, religion) and socio-economic (type of employment, standard of living) characteristics of the population. Six indicators were used as predictors (all as relative values in respective municipality): citizens over the age of 65, people with university degree, Catholics, the unemployed, private entrepreneurs and people facing distraint (whose property was confiscated due to unpaid debts). The gender factor also has a significant influence on voting behaviour in Czechia (Řeháková 1999), but this variable (proportion of men and women) shows very little variability in space, so it makes no sense to include it in regression models. Its influence would have to be observed at the individual level, not on aggregated data.

One of the outputs of the multiple linear regression are residuals, which for each political party show the differences between its actual electoral support in the Czech parliamentary elections 2017 and the electoral support predicted on the basis of the social composition of the population in each municipality. When the residual value is positive, it means that the political party had higher electoral support in the municipality than we would expect according to the regression model. In this respect, the studied friends and neighbours effect or other contextual factors can often play an important role in explaining these deviations.

The analysis of residuals was used for two main purposes: 1) to measure the strength of the friends and neighbours effect in the municipalities whose mayor figured on the candidate list of any of the nine analysed political parties; 2) to observe the spatial extent of the local influence of the mayors on candidate lists on the example of the political movement STAN. The first of these two points of the analysis was supplemented by the search for correlation between the strength of the friends and neighbours effect and the population of the municipality to which this effect relates. Information about the place of residence and occupation of all candidates is available on the website of Czech Statistical Office (2017). The analyses included candidates who have stated "mayor" as their occupation on the list of candidates.

Municipalities with mayors on candidate lists were divided into seven categories according to their number of inhabitants. Mean, $\alpha$-trimmed mean $(\alpha=5 \%)$ and median of the residual values of the electoral support of the political parties represented by the candidates (analysed mayors) were calculated. The less frequently used term $\alpha$-trimmed mean is a mathematical quantity, in the calculation of which $\alpha$ of the smallest and largest values 
are separated from the original dataset and the arithmetic mean is calculated from the remaining $(100-2 \alpha) \%$ values (Hendl 2006).

The method of local hot spot analysis was applied to study the spatial extent of the friends and neighbours effect. This tool makes it possible to identify spatial clusters of territorial units that have significantly above-average or below-average values of the observed phenomenon. In our case, these were clusters of municipalities with significantly positive or negative residuals as differences between actual and expected electoral support. A constant limit distance model set at $10 \mathrm{~km}$ was used to calculate the spatial weights. This distance is used in analyses for Czech municipalities mainly because each municipality should have at least one neighbouring unit in the analysis (the largest distance of a municipality from its nearest neighbouring municipality in Czechia is $9.4 \mathrm{~km})$.

Clusters of positive residuals are relevant in determining the influence of the friends and neighbours effect. Although there may be a negative friends and neighbours effect as well, its strength and spatial extent is usually not large enough to manifest itself as a cluster of negative residuals, which therefore have different causes. Local hot spot analysis was previously used by Bernard, Kostelecký and Šimon (2014) to capture various types of spatial contextual influences on voter decision-making in Czech parliamentary elections. According to them, research at the lowest possible scale level makes it possible to reveal even quite small site-specific deviations of electoral behaviour. It is the reason why municipalities were chosen as the basic spatial units of all analyses also in my study.

The study works with open data of the results of the Czech parliamentary elections 2017, which are administered by the Czech Statistical Office (2017). However, these are not election data for municipalities, but for individual polling stations, therefore their aggregation to the level of municipalities was necessary. At the level of polling stations, there are no available data about the composition of their population. These are accessible in a very detailed form for all Czech municipalities (a total of 6,258 municipalities) thanks to the regular population census, which last took place in 2011 (Czech Statistical Office 2011).

It would be more appropriate if we had similar data for the year when the analysed elections took place, as the composition of the population of some municipalities could partially change between 2011 and 2017, which would affect the relevance of the research results. However, six years is not that long time in terms of socio-demographic changes and also dynamic population changes occur only in some specific localities, for example in suburban areas in the hinterland of cities such as Prague or Brno (Novák and Netrdová 2011). The additional source was the database about people, whose property was confiscated due to unpaid debts, and their share in individual municipalities in the Czechia, provided by the Institute of Sociology of the Czech Academy of Sciences (Hábl 2017).

A methodological problem that has accompanied geographical research conducted in the Czech electoral environment for many years is the fact that Czech citizens are not obliged to vote in their municipality of residence, but can apply for a so-called voting card that entitles them to vote in any polling station across the country. This alternative is used by a large number of voters in Czechia, but the number of used voting cards is not ascertainable. The high proportion of such voters causes deviations from spatial patterns of voting behaviour, especially in tourist attractive localities such as Krkonoše (Giant Mountains) or Šumava (Bohemian Forest), where many tourists, for example from Prague and its surroundings or other bigger cities, cast their votes (Bernard, Kostelecký, and Šimon 2014).

\section{Research results and discussion}

In the Czech parliamentary elections 2017, we could observe significant spatial differences in election results. In some localities, populist parties, which in Czechia include SPD movement, but also ANO or KSČM (Bendl, Bořil, and Suchánek 2020), had very above-average support, while in other localities most voters preferred liberal-oriented political parties. Using multiple linear regression analysis, it was possible to determine the dependence of electoral support of all nine successful political parties on the structure of the population of Czech municipalities (Tab. 1), which partly explains the territorial differentiation of election results and spatial patterns of electoral behaviour in Czechia.

The winning political movement ANO received above-average electoral support in areas with a smaller share of private entrepreneurs and university-educated people and also in places with a higher unemployment rate. A similar association was manifested in the electoral support of KSČM and SPD. Both of them received above-average electoral gains also in localities with a higher proportion of people facing distraint, who vote more often for these anti-system political parties.

The only major difference in the dependencies of the electoral support of the two discussed parties is the influence of the share of seniors (aged over 65) on their election result in the respective municipality. While the Communists benefit from a higher proportion of seniors, as do other from traditional left-wing political parties - ČSSD, the new (founded in 2015) farright political movement SPD led by Tomio Okamura had significantly lower electoral support in municipalities with a higher share of elderly citizens. 
Tab. 1 Dependence of electoral support of political parties in the Czech parliamentary elections 2017 on the structure of population at the level of municipalities (standardized beta coefficients of multiple linear regression models).

\begin{tabular}{|c|c|c|c|c|c|c|c|c|c|}
\hline \multirow{2}{*}{$\begin{array}{c}\text { Independent } \\
\text { variables - Share } \\
\text { in the population }\end{array}$} & \multicolumn{9}{|c|}{ Dependent variables - Electoral support of particular political parties } \\
\hline & ANO & ODS & Piráti & SPD & KSČM & ČSSD & KDU-ČSL & TOP 09 & STAN \\
\hline University graduates & -.201 & .318 & .204 & -.141 & -.243 & -.091 & .032 & .376 & \\
\hline Catholics & -.240 & -.185 & -.190 & & -.117 & .105 & .793 & -.142 & -.176 \\
\hline Unemployed & .041 & -.173 & -.154 & .163 & .188 & & .024 & -.092 & -.075 \\
\hline Aged over 65 & & & -.028 & -.102 & .110 & .137 & -.036 & & \\
\hline Private entrepreneurs & -.193 & .251 & .144 & -.026 & -.144 & -.090 & -.028 & .185 & .096 \\
\hline Facing distraint & & & -.057 & .068 & .034 & & -.037 & & -.055 \\
\hline$R$ square & .156 & .289 & .166 & .091 & .193 & .060 & .641 & .248 & .047 \\
\hline
\end{tabular}

Sources: Czech Statistical Office (2011; 2017), Hábl (2017); author's calculations.

Note: Only statistically significant values are shown in the table $(p<0.05)$.

The electoral preferences of KDU-ČSL in individual municipalities are very strongly correlated with the share of Catholics. This dependence is confirmed by many other studies of electoral behaviour patterns in Czechia, such as Voda (2010), who determined using the binary logistic regression method that the probability of voting KDU-ČSL is 26 times higher for a person who goes to church at least once a month in comparison with those who do not. Other determinants of the electoral support of this political party are also statistically significant at the level of municipalities, but all of them are very weak with the standardized beta coefficients lower than \pm 0.04 (Tab. 1).

An interesting finding is the similarity of the results of multiple linear regression models for four different political parties: ODS, Piráti, TOP 09 and STAN. All of them could be classified as liberal-oriented entities, and at the same time they all ended up in opposition after the Czech parliamentary elections 2017. Electoral support of these four political parties is above-average in municipalities with a higher share of private entrepreneurs, lower unemployment rate, a lower share of Catholics and, with the exception of STAN, also in municipalities with a higher share of university-educated people. This is an indicator for which we record a strong positive correlation dominantly with the electoral preferences of TOP 09 and ODS.

In Tab. 1, the last row shows the coefficients of determination (R square) for all nine regression models. This value denotes to what extent the spatial differentiation of electoral support of a particular political party can be explained on the basis of the heterogeneous structure of the population of Czech municipalities. Most, specifically $64.1 \%$ of the variability was explained in the electoral support of KDU-ČSL, primarily due to the religion factor and the higher electoral gains of the party in Catholic areas. On the contrary, the electoral support of STAN is the least determined by the composition of population. The regression model for this party explained only $4.7 \%$ of the variability of its electoral gains at the level of municipalities. This indicates the need to look for other, especially various contextual, factors, such as the friends and neighbours effect, that would better explain the spatial patterns of electoral preferences.

\subsection{Mayors on candidate lists}

The friends and neighbours effect should, by its very nature, be most evident on the instance of strong and well-known, but at the same time strongly locally connected personalities. As more than 7,500 candidates took part in the studied parliamentary elections (Czech Statistical Office 2017), it would be very difficult to analyse the electoral support in their home municipalities for all of them. Therefore, only one specific group of candidates was selected - the mayors of Czech municipalities, for whom existence of the effect could be reasonably expected. Mayors are usually candidates that local citizens know and trust, which is an important prerequisite for why, thanks to their candidacy, voters in the respective municipalities could also support the political parties and movements represented by them.

A total of 358 mayors were present on the candidate lists of the nine analysed political parties in the Czech parliamentary elections 2017. The largest share from this number belongs to the STAN candidates, among which there were 166 mayors of Czech towns and municipalities. In terms of representation of other political parties, 41 mayors sought parliamentary seats as ODS candidates, KDU-ČSL had 40, ČSSD 38, ANO 27, TOP 09 24, KSČM 20, Piráti only two and SPD none of mayors on its candidate lists. These values could partly reflect the strength of political parties in Czech local politics and also the "bottom up tendencies" of their candidates. While an ascending political career paths are typical for STAN candidates, SPD is much more nationwide without emphasis on the local level.

The attached Fig. 1 shows the map of municipalities whose mayors appeared on the candidate lists in the 


\section{Political parties (and numbers) of candidates-mayors}

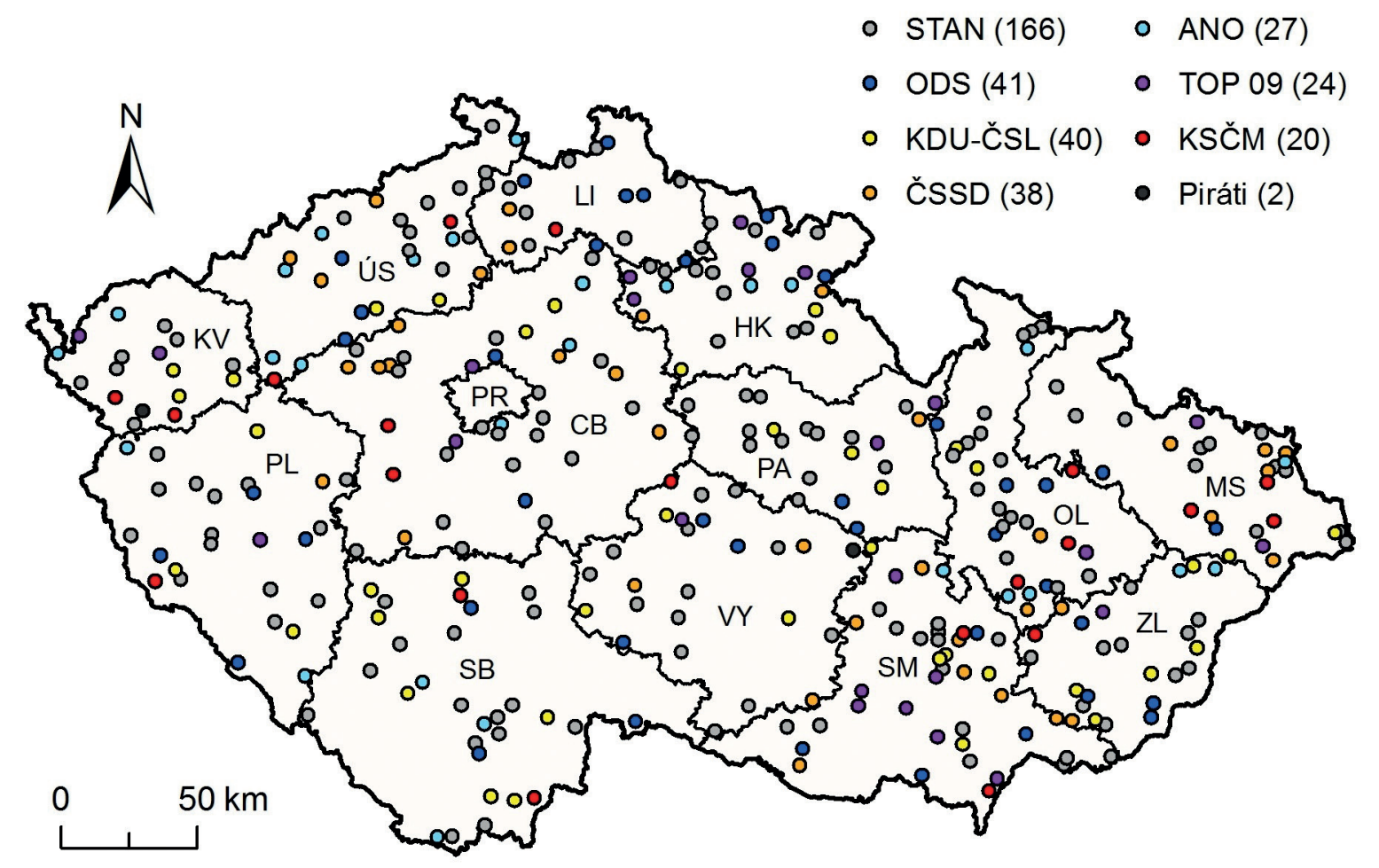

Fig. 1 Geographical distribution of mayors participating in the Czech parliamentary elections 2017.

Sources: Arcdata Praha (2016), Czech Statistical Office (2017); composed by author.

Notes: List of regions (abbreviations): Central Bohemian Region (CB), Hradec Králové Region (HK), Karlovy Vary Region (KV), Liberec Region (LI), Moravian-Silesian Region (MS), Olomouc Region (OL), Pardubice Region (PA), Plzeň Region (PL), Prague (PR), South Bohemian Region (SB), South Moravian Region (SM), Ústí nad Labem Region (ÚS), Vysočina Region (VY), Zlín Region (ZL). The map only includes data on mayors on the candidate lists of political parties that have exceeded the $5 \%$ quorum.

analysed elections. Their spatial distribution was relatively even, yet the map shows regions in which their significantly higher concentration is evident compared to other areas, such as the region of Central Moravia. At the same time, individual parties and movements had their candidate mayors very spatially dispersed as well, and no significant clustering of mayors of any of the political entities into a specific locality could be observed. An example of a party whose candidates from among the mayors of Czech municipalities show a certain degree of spatial clustering would be TOP 09 , where 12 out of 24 mayors on the party's candidate lists were registered in just two regions: South Moravian Region and Hradec Králové Region, where the political party was generally relatively stronger in comparison with the rest of the country, except Prague.

Mayors from variously large municipalities appeared on the candidate lists (Tab. 2). Both very small municipalities and big towns, including the regional capitals, were represented. However, mayors from smaller municipalities in most cases only supplemented the regional candidate lists and were placed on the bottom of the lists, without a reasonable chance of success. Martin Kupka from Líbeznice (2,207 inhabitants in 2011) was the only mayor of a small municipality who managed to obtain the mandate in the Chamber of Deputies from almost the last place (position 31 out of a total of 34 candidates) on the candidate list thanks to a large number of preferential votes. The explanation of his success may be that he also works as a councillor of the Central Bohemian Region and since 2014 also as a vice-chairman of ODS, so his local competence is therefore wider and his name and face are not known only to the citizens of his municipality, but to the inhabitants of the whole region.

Tab. 2 Mayors on candidate lists according to the population size of the municipality.

\begin{tabular}{|l|c|c|}
\hline $\begin{array}{l}\text { Population of the } \\
\text { municipality }\end{array}$ & $\begin{array}{l}\text { Number of } \\
\text { mayors on } \\
\text { candidate lists }\end{array}$ & $\begin{array}{l}\text { Number of successful } \\
\text { candidates out of these } \\
\text { mayors }\end{array}$ \\
\hline Under 500 & 35 & 0 \\
\hline $501-1000$ & 63 & 0 \\
\hline $1001-1500$ & 47 & 0 \\
\hline $1501-2500$ & 64 & 2 \\
\hline $2501-5000$ & 53 & 0 \\
\hline $5001-10000$ & 45 & 1 \\
\hline Over 10000 & 51 & 9 \\
\hline Total & 358 & 12 \\
\hline
\end{tabular}

Source: Czech Statistical Office (2017); author's calculations. Notes: Values in the table include nine successful political parties in the analysed elections. A successful candidate is the one who earned a seat in the Chamber of Deputies. 
A total of 12 mayors won a seat in the Chamber of Deputies. Half of them headed the regional candidate list of their political party, and at the time of the elections in October 2017 they were top representatives of towns with more than 10,000 inhabitants (namely Jablonec nad Nisou, Kolín, Mariánské Lázně, Náchod, Trutnov and Uherské Hradiště). From the sixth place on the ODS candidate list in the Pardubice Region, the very popular and long-time mayor of Polička (population of approximately 8,800 inhabitants) Jaroslav Martinů managed to succeed. He received more than half of the preferential votes, thanks to which he became a deputy, in Polička and the nearby hinterland. This indicates a significant spatial concentration of preferential votes, which is one of the direct manifestations of the friends and neighbours effect in the Czech parliamentary elections (Voda and Pink 2009).

\subsection{Measuring friends and neighbours effect at the level of municipalities}

A secondary manifestation of the friends and neighbours effect in parliamentary elections in Czechia may be significantly higher electoral support of political parties in municipalities and localities where some of their candidates live. As part of the analysis of the influence of mayors on the electoral behaviour of the inhabitants of the respective municipalities, residuals from regression models were used to measure the strength of the effect, which show deviations in the electoral gain of each of the nine successful political parties in individual municipalities in Czechia. In other words, this method can be used to monitor where do the parties have higher and where, on the contrary, lower electoral support, after removing the influence of spatially differentiated socio-demographic and socio-economic structure of the population.

In most municipalities, specifically in 341 out of 358 municipalities with a mayor as a candidate in the parliamentary elections, which means $95.3 \%$ of all cases, the calculated residuals acquired positive values (see Fig. 2). This statistically proves that it is not only a random deviation, but a systematic influence of the candidacy of the local mayors on the election results in the respective municipalities. The average value of regression residuals was $6.7 \%$. This result can be interpreted as that if a mayor ran in the Czech parliamentary elections 2017, the electoral gain of the political party he represented was in his municipality on average 6.7 percentage points higher than we would expect based on the municipality's population characteristics.

\section{Residual value of electoral support}

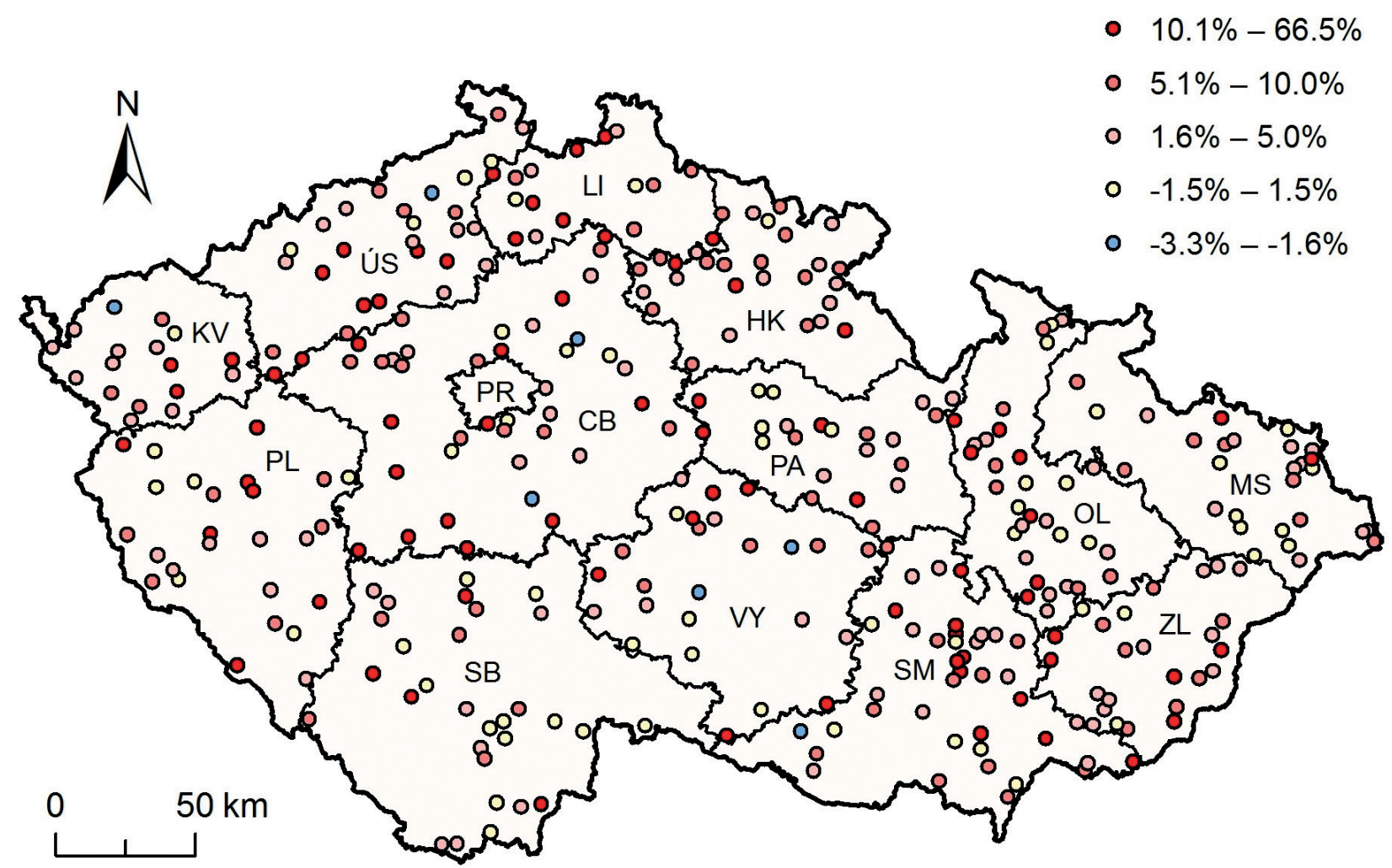

Fig. 2 Differences between actual and expected electoral support of political parties in the municipalities where their candidates-mayors live.

Sources: Arcdata Praha (2016), Czech Statistical Office (2011; 2017), Hábl (2017); composed by author (including own calculations).

Note: The same abbreviations of regions are used in the map as in Fig. 1. The map only includes data on mayors on the candidate lists of political parties that have exceeded the $5 \%$ quorum. 
However, the arithmetic mean can be greatly affected by extreme values, so it would be more appropriate to work with, for example, the median or $\alpha$-trimmed mean. The median electoral support residual is $4.8 \%$, almost two percentage points lower than the mean, and the $\alpha$-trimmed mean is $6.0 \%$. As it turns out, the mean is increased by extreme observations, so it is influenced mainly by extremely high residual values. The highest residual of electoral support was recorded in the Central Bohemian village of Těchařovice, whose mayor Vanda Bělinová appeared on the ČSSD candidate list and the party won $73.9 \%$ of valid votes in this village (residual $+66.5 \%$ ). In absolute numbers, however, it was only 17 votes out of a total of 23 , and this extreme local support had virtually no impact on the party's result in the wider region.

As we can see from Fig. 2, there are no significant spatial patterns and differences among the Czech regions in relation to the strength of the friends and neighbours effect analysed on the example of mayors as candidates in the parliamentary elections. Municipalities with a residual value higher than $10 \%$, of which there are a total of 78, are spread throughout the whole country. There are most such municipalities in the Central Bohemian Region - a total of 13, on the other hand the least in the Moravian-Silesian Region - only two. Similarly, municipalities with more noticeably negative residuals (below $-1.5 \%$ ) are not located in one specific region, but can be found in different parts of Czechia.

It is also interesting to look at the municipalities in which the residual of the electoral support of the relevant political party was negative. In addition to large cities, relatively small villages can be found among 17 of them as well. An example is the Staré Město pod
Landštejnem, where ODS had a lower electoral preferences than predicted by the theoretical regression model, even though the mayor of the village, Alena Šindlerová, was present on the candidate list. In a village with about 500 inhabitants we would definitely not expect something similar, but it turns out that the sole presence of the candidate on the list is not sufficient if it is not connected with his quality or popularity among local residents, as evidenced by the significant decline of ODS support in this village between municipal elections in 2014 and 2018.

The magnitude of the candidate mayor's influence on the election result of the relevant party in the respective municipality shows considerable variability across the 358 analysed candidates. Foreign studies (Tatalovich 1975; Lewis-Beck and Rice 1983; Gimpel et al. 2008), as well as Czech ones (Malcová 2012), agree that the most important determinant of the strength of the friends and neighbours effect is the population size of the municipality or region to which the effect relates. This relationship was also demonstrated on the example of mayors as candidates in the Czech parliamentary elections 2017. The highest average strength of the friends and neighbours effect is clearly evident in the smallest municipalities. With the growing number of inhabitants in the municipality, the strength of the effect gradually decreases (Fig. 3).

The increase in electoral support of the relevant political party or movement thanks to the local mayor on the candidate list reaches in municipalities with less than 500 inhabitants on average 16 percentage points. The values of regression residuals are also above-average in next two size categories, including municipalities with the population between 500 and 1,500 inhabitants. In towns, on the other hand,

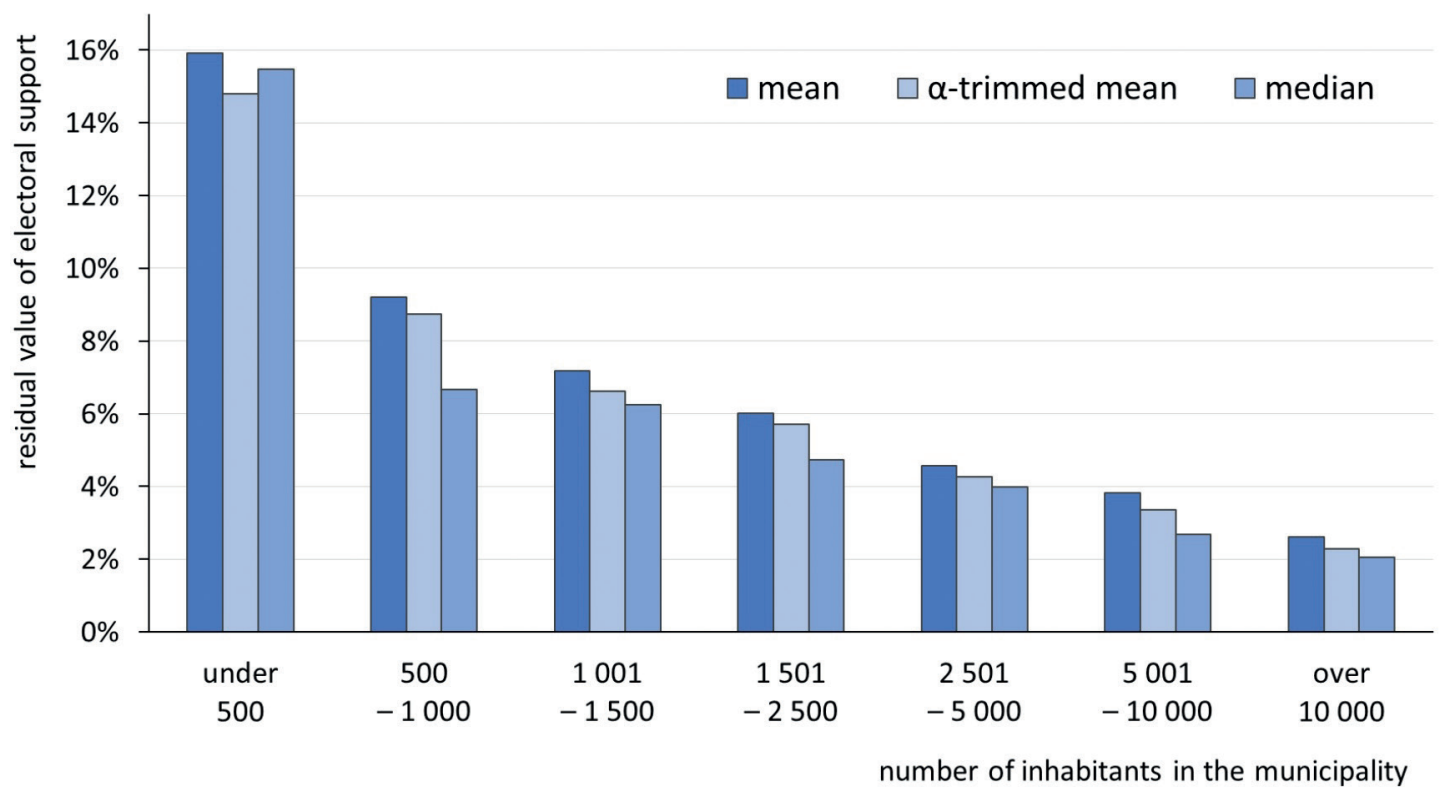

Fig. 3 Increased local electoral support of a political party thanks to the mayor on the candidate list, depending on the population size of the municipality.

Sources: Czech Statistical Office (2011; 2017), Hábl (2017); composed by author (including own calculations). 
the influence of the friends and neighbours effect on the election results is much more marginal in relative terms, which, however, is not true when converted to the absolute number of voters. Moreover, even in some (bigger) towns, the strength of the effect reaches considerably high values, suggesting the quality and popularity of the local mayors. An example is the candidacy of Vít Rakušan, the mayor of Kolín (residual $+20.8 \%$ ), the already mentioned mayor of Polička, Jaroslav Martinů (+12.5\%) or Petr Třešňák from Mariánské Lázně (+7.9\%).

There are many reasons why the candidacy of strong local personalities, such as mayors, has a greater impact on changes in electoral preferences in small municipalities. In the very smallest municipalities, even personal acquaintance and relations between the mayor and the citizens can be expected. Citizens of a small municipality identify more with their mayor as a candidate for the Chamber of Deputies and appreciate the opportunity to support someone they know very well in the elections.

With the growing size of the municipality, the intensity of social ties and social cohesion among its citizens decreases. An important explanatory factor is also the growing number of competing candidates from the same municipality on candidate lists of various political parties, as a result of which the so-called personal votes associated with the presence of a local candidate, whom voters would consider their "neighbour", are divided between more parties.

Differences in the strength of the friends and neighbours effect can be observed also between groups of candidates-mayors representing different political parties. The average residual value of electoral support ( $\alpha$-trimmed mean) was the highest in municipalities with mayors on the candidate lists of KSČM (8.6\%). Compared to other political parties or movements, this value was more than two percentage points higher, which can be explained by the smallest average population size of respective municipalities (approximately 1,400 inhabitants), whose mayors were candidates for this party.

\subsection{Spatial extent of the effect on the example of STAN candidates}

The friends and neighbours effect does not influence voter decision-making only in specific municipalities, as presented in previous chapter, but also at higher geographical scale levels. Therefore, the impact of the effect of mayors on candidate lists was analysed through a local hot spot analysis, which allows to monitor larger areas under their influence. The spatial patterns of electoral support of STAN were examined. This political movement is dominantly based on well-known personalities from the local politics of Czech towns and municipalities. At the same time, the territorial differentiation of STAN's electoral preferences can hardly be explained through the spatially heterogeneous composition of the population at the municipal level (Tab. 1). These are the reasons why we can assume that the differences in the party's electoral gains between different localities are particularly influenced by contextual factors, such as the friends and neighbours effect.

The political party recorded the highest support in the Czech parliamentary elections 2017 in the Liberec Region (Czech Statistical Office 2017). The main reason was the performance of a strong regional political subject Mayors for the Liberec Region (SLK), which has already won the regional elections there three times in a row. A large part of the candidates elected as the regional representatives were also on the STAN candidate list in the parliamentary elections, including Martin Půta, the regional council president of the Liberec Region. This resulted in significantly higher STAN electoral support in the entire region than expected by the regression model (Fig. 4).

Another very large cluster of municipalities with higher than expected STAN electoral support was located in the Central Bohemian Region, specifically in its eastern part. This local hot spot can be partly explained by the friends and neighbours effect associated with the mayor of Kolín, Vít Rakušan. The spatial cluster of positive residuals covered in all directions the area to an air distance of approximately $25 \mathrm{~km}$ from Kolín, which may show the distance to which voters still considered this candidate, STAN leader in the Central Bohemian Region, as their "neighbour" and thus influenced their voting behaviour.

In the Central Bohemian Region we can observe also several smaller areas under the influence of the effect. These are, for example, the immediate vicinity of municipalities such as Petrovice, Hvoždany or Kroučová, whose mayors also ran in the 2017 parliamentary elections for STAN and received higher electoral preferences in their home locations not only for themselves but for the political party they represented as well. Although these three municipalities are located in different parts of the region, in terms of their location we could include all of them in the so-called inner periphery of Czechia, situated at the regional borders between administrative units within the country (Musil and Müller 2008). One of the causes of a stronger manifestation of the friends and neighbours effect in such localities may be the fact that candidates from the peripheral areas of the state usually have an easier position in terms of less potential local rivalry (Gimpel et al. 2008).

The opposite situation was recorded on the example of Věra Kovářová, the former mayor of Chýně, west of Prague. Despite the fact that she is a regional representative and a deputy who ran from second place on the STAN candidate list, her candidacy did not transform into above-average electoral support of the party anywhere else than in the respective municipality. This contrast was also evident in other candidates from different localities of the Central Bohemian Region and shows differences in the strength of the 


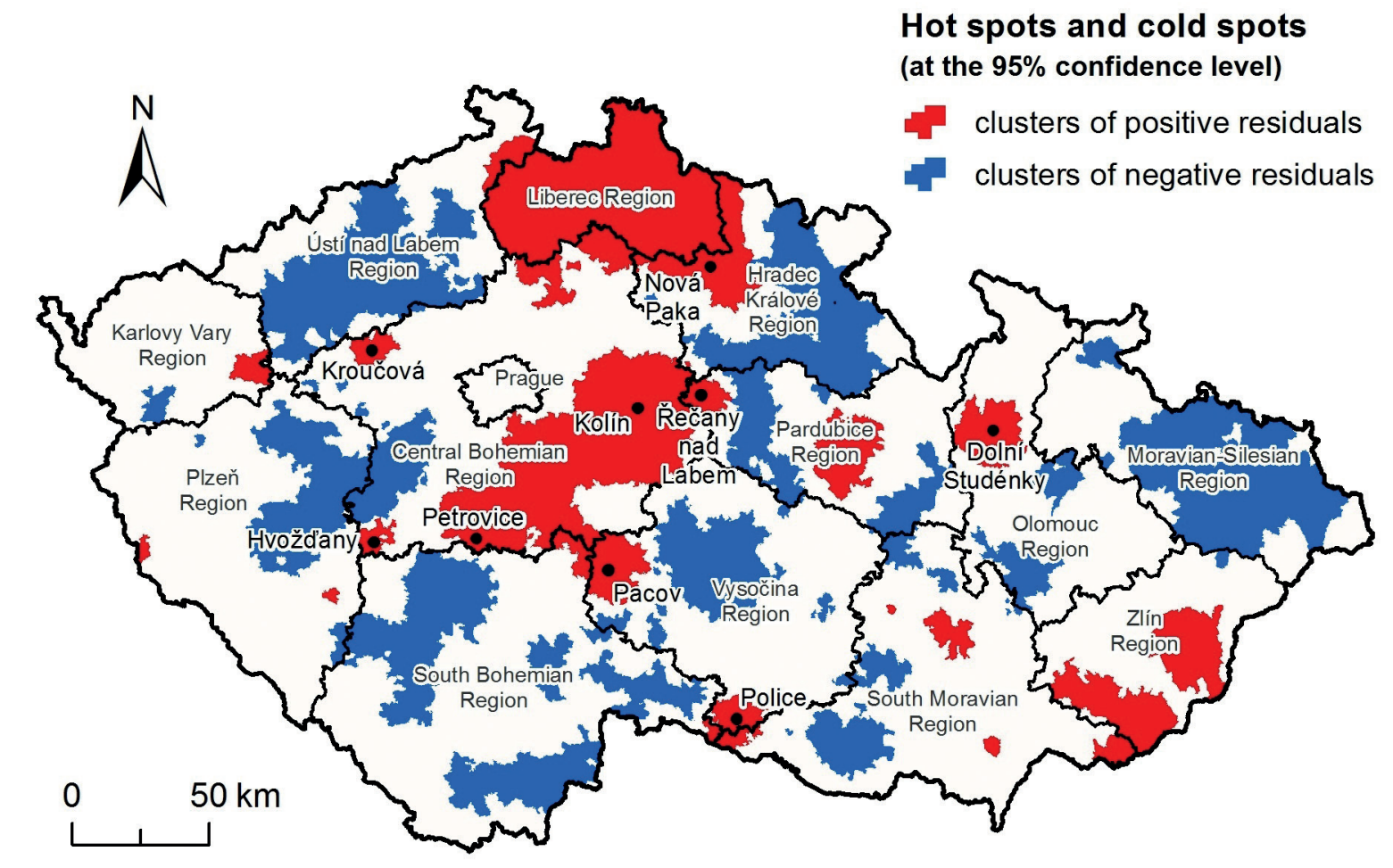

Fig. 4 Spatial clusters of positive and negative residuals of STAN electoral support.

Sources: Arcdata Praha (2016), Czech Statistical Office (2011; 2017), Hábl (2017); composed by author (including own calculations).

friends and neighbours effect and its spatial extent between candidates from the metropolitan area and the peripheral countryside.

Also in other regions, clusters of positive residuals connected with the friends and neighbours effect, specifically with the influence of the mayors on the STAN candidate lists, are more often found in peripheral, or at least in non-metropolitan areas (Fig. 4). Most of them are candidates from the forefront of candidate lists in the respective regions. In the Hradec Králové Region, the STAN electoral support hot spot is located in the north-western part of the region, especially in the area around the town of Nová Paka, whose mayor Josef Cogan ran from the first place on the regional candidate list.

The same situation is observable in the Pardubice region, where STAN had significantly higher than the regression model expected (based on the population structure) electoral support in the western part of the region, around Řečany nad Labem. The mayor of this municipality Michaela Matoušková was also one of the regional leaders of STAN in the Czech parliamentary elections 2017. Two mayors in the leading positions of the candidate list in the Vysočina Region - namely Lukáš Vlček from Pacov and Karel Janoušek from Police - also contributed to the statistically significant increase in the party's electoral support in the localities of their residence.

A similar example of the friends and neighbours effect is the candidacy of Radim Sršeň, mayor of Dolní Studénky and the regional leader of STAN in the
Olomouc Region. The spatial cluster of municipalities with positive residuals surrounds Dolní Studénky approximately to a distance of $15 \mathrm{~km}$ from the municipality, which is located in its center. The majority of preferential votes cast for Radim Sršeň are also concentrated in this micro-region.

To more accurately determine the impact of the friends and neighbours effect, more than one parliamentary elections should be analysed, using a longitudinal approach to monitor changes in spatial patterns of political party electoral support. This would better show whether in some of the localities associated with the influence of the studied effect, the party's support was not significantly higher already before 2017, when the local personality did not run in the elections. However, STAN is a relatively new political movement, competed in 2017 as an independent political party for the first time, so this longitudinal view is not applicable. Fig. 4 also depicts as clusters of positive residuals some localities which cannot be unambiguously connected with the friends and neighbours effect. The reason for higher electoral support is not always clear and detectable using the presented methodology, for example in the area in the middle of the Pardubice Region.

\section{Conclusions}

Territorial differences in the results of the Czech parliamentary elections 2017 at the level of municipalities 
can be partially explained by heterogeneous population structure (different share of university-educated people, private entrepreneurs, Catholics, senior citizens, unemployed or people with debts, facing distraint), but the majority of spatial variability of electoral support of individual political parties remains unexplained using this compositional approach. The only exception in the Czech parliamentary elections is the political party KDU-ČSL, whose electoral preferences are strongly dependent on the degree of religiosity. This strong dependence is also documented by other geographical studies of the Czech parliamentary elections (Kouba 2007; Kostelecký 2009; Voda 2010).

The article shows that the voter is not only an isolated individual, but part of a system in which his voting decisions are influenced by the spatial context of the locality where he lives. In this respect, the connection of specific individuals on candidate lists with certain localities is very important. It has been shown on the example of mayors that candidates receive significantly above-average electoral support not only for themselves through preferential voting, but also for the political party they represent, through higher percentage of electoral votes, in their municipality of residence. Therefore, this contribution represents an empirical evidence of the validity of the theoretical concept of the friends and neighbours effect in Czechia.

The mayor's candidacy for the Chamber of Deputies has a greater impact on voting behaviour in smaller municipalities, which corresponds to theoretical assumptions and empirical results of older research (Gimpel et al. 2008; Malcová 2012). In bigger towns, the relationship between the mayor and the citizens is usually not so close. At the same time, the importance of friends and neighbours effect is diminished due to larger number of candidates from the same town on the candidate lists of different political parties which results in more competition among local candidates. The key factor is not only the size of the municipality, but also the popularity of the mayor and the perception of his involvement in solving local problems and the organization of community life. The effect is most intense in the municipalities of candidates' residency, but it can also be seen in the adjacent municipalities or even in the wider micro-region.

The spatial patterns of STAN electoral support highlighted a stronger friends and neighbours effect for candidates from non-metropolitan areas, specifically from the inner peripheries near the administrative borders between Czech regions. This finding agrees with the conclusions of the work of Blais et al. (2003) from Canada, where the candidacy of a strong local personality also has a greater influence on voting behaviour in rural areas. As expected, the effect was most noticeable for regional leaders of the party, generally for mayors from the forefront of candidate lists, who are usually also more promoted in election campaigns.
The results, which show a significant influence of local candidates on voter decision-making in the Czech electoral environment, are also applicable in practice. The potential of the friends and neighbours effect could be used by political parties in the process of drawing up candidate lists or in the implementation of locally targeted election campaigns. A concrete example from Czechia is the election strategy of the regional political movement Jihočeši 2012, the main motto of which is the slogan "We are your neighbours".

It is very difficult to estimate in which direction the factors influencing voting behaviour will develop in the future. There is certainly no evidence that the friends and neighbours effect should lose its significance. On the contrary, recent studies of the Czech electoral environment (Malcová 2012; Mikešová 2019) mention its growing relevance, related to tendencies to personalise politics and promote strong candidates, including local ones, in election campaigns. The question of who is running for a particular political party is increasingly important for voter decision-making, compared to the declining interest in election programs (Linek and Voženílková 2017).

\section{Acknowledgements}

The study was supported by the Charles University, project GA UK No. 265521. This paper is partly based on the results of the author's diploma thesis, supervised by Tomáš Kostelecký.

\section{References}

Agnew, J. (1996): Mapping politics: how context counts in electoral geography. Political Geography 15(2), 129-146, https://doi.org/10.1016/0962-6298(95)00076-3.

Arcdata Praha (2016): ArcČR 500, version 3.3 [data set], http://www.arcdata.cz/produkty-a-sluzby /geograficka-data/arccr-500.

Arzheimer, K., Evans, J. (2012): Geolocation and voting: Candidate-voter distance effects on party choice in the 2010 UK general election in England. Political Geography 31(5), 301-310, https://doi.org/10.1016/j.polgeo .2012.04.006

Baumann, Z., Winburn, J., Russo, S. J., Islam, M. S. (2021): What Are Friends for? The Effect of Geographic Proximity on Primary Turnout in Gubernatorial Elections. Political Research Quarterly 74(2), 317-331, https://doi.org/10.1177/1065912920906202.

Bendl, T., Bořil, V., Suchánek, J. (2020): Populismus, migrace a virtuální svět. Geografické rozhledy 29(5), 4-7.

Bernard, J., Kostelecký, T. (2014): Prostorový kontext volebního chování - jak působí lokální a regionální prostředí na rozhodování voličů. Sociologický časopis / Czech Sociological Review 50(1), 3-28, https://doi.org /10.13060/00380288.2014.50.1.30.

Bernard, J., Kostelecký, T., Šimon, M. (2014): Existují prostorové kontextové vlivy na volební chování i v relativně nacionalizovaném stranickém systému? 
příklad Česka. Geografie 119(3), 240-258, https://doi .org/10.37040/geografie2014119030240.

Blais, A., Gidengil, E., Dobrzynska, A., Nevitte, N., Nadeau, R. (2003): Does the Local Candidate Matter? Candidate Effects in the Canadian Election of 2000. Canadian Journal of Political Science 36(3), 657-664, https://doi .org/10.1017/S0008423903778810.

Butler, D., Stokes, D. (1969): Political Change in Britain: Forces Shaping Electoral Choice. New York: St. Martin's Press.

Cox, K. R. (1969): The Voting Decision in a Spatial Context. Progress in Geography 1, 81-117.

Czech Statistical Office (2011): Sčítání lidu, domů a bytů 2011 [data set], https://www.czso.cz/csu/sldb.

Czech Statistical Office (2017): Volby do Poslanecké sněmovny Parlamentu České republiky konané ve dnech 20. 10. - 21.10. 2017 [data set], https://www.volby.cz /cz/ps2017.htm.

Denver, D. T., Hands, G. (1993): Measuring the intensity and effectiveness of constituency campaigning in the 1992 general election. In Denver, D. T., Norris, P., Broughton, D., Railings, C. (eds.). British Elections and Parties Yearbook 1993. Hemel Hempstead: Harvester Wheatsheaf, 229242, https://doi.org/10.1080/13689889308412934.

Dýnková, H. (2017): Analýza výsledků voleb do Poslanecké sněmovny Parlamentu ČR 2017, https://medium.com /@dynkova.hana.

Gimpel, J. G., Karnes, K. A., McTague, J., Pearson-Merkowitz, S. (2008): Distance-decay in the political geography of friends-and-neighbors voting. Political Geography 27(2), 231-252, https://doi.org/10.1016/j.polgeo.2007 10.005 .

Górecki, M. A., Marsh, M. (2012): Not just 'friends and neighbours': Canvassing, geographic proximity and voter choice. European Journal of Political Research 51(5), 563-582, https://doi .org/10.1111/j.1475-6765.2011.02008.x.

Harbers, I. (2017): Spatial effects and party nationalization: The Geography of partisan support in Mexico. Electoral Studies 47(1), 55-66, https://doi.org/10.1016 /j.electstud.2016.11.016.

Hábl, R. (2017): Mapa exekucí [data set], http:// mapaexekuci.cz/index.php/mapa-2.

Hendl, P. (2006): Přehled statistických metod zpracování dat. Praha: Portál.

Hloušek, V. (2002): Koncept konfliktních linií ve střední a jihovýchodní Evropě - tři roviny analýzy. Středoevropské politické studie 4(2-3), 1-10.

Inglehart, R. F., Norris, P. (2016): Trump, Brexit, and the rise of populism: Economic have-nots and cultural backlash. HKS Faculty Research Working Paper Series. Cambridge: Harvard University, https://doi.org/10.2139/ssrn .2818659 .

Johnston, R., Pattie, C. (1997): Where's the Difference? Decomposing the Impact of Local Election Campaigns in Great Britain. Electoral Studies 16(2), 165-174, https:// doi.org/10.1016/S0261-3794(96)00064-9.

Johnston, R., Wickham-Jones, M., Pattie, C., Cutts, D., Pemberton, H. (2016): Friends and neighbours voting revisited: The geography of support for candidates to lead the UK's Labour party. Political Geography 55, 1-9, https://doi.org/10.1016/j.polgeo.2016.02.003.

Kal Munis, B. (2021): Place, candidate roots, and voter preferences in an age of partisan polarization:
Observational and experimental evidence. Political Geography 85, 1-12, https://doi.org/10.1016/j.polgeo .2021.102345.

Kitschelt, H. (1994): The Transformation of European Social Democracy. Cambridge: Cambridge University Press, https://doi.org/10.1017/CB09780511622014.

Kostelecký, T., Čermák, D. (2004): Vliv teritoriálně specifických faktorů na formování politických orientací voličů. Sociologický časopis / Czech Sociological Review 40(4), 469-487, https://doi.org/10.13060/00380288 .2004.40.4.05.

Kostelecký, T. (2009): Regionální rozdíly ve volebních výsledcích v České republice - parlamentní volby 19962006. Evropská volební studia / European Electoral Studies 4(2), 124-134.

Kouba, K. (2007): Prostorová analýza českého stranického systému. Institucionalizace a prostorové režimy. Sociologický časopis / Czech Sociological Review 43(5), 1017-1037, https://doi.org/10.13060/00380288.200 .43.5.08.

Kowalski, M. (1999): Electoral Geography in Poland. In Duró, A. (ed.). Spatial Research in Support of the European Integration. Pécs: Centre for Regional Studies, 87-95.

Lepič, M. (2017): Limits to territorial nationalization in election support for an independence-aimed regional nationalism in Catalonia. Political Geography 60, 190202, https://doi.org/10.1016/j.polgeo.2017.08.003.

Lewis-Beck, M. S., Rice, T. W. (1983): Localism in Presidential Elections: The Home State Advantage. American Journal of Political Science 27(3), 548-556, https://doi.org/10.2307/2110984.

Linek, L., Voženílková, M. (2017): Strany na ústupu, lídři na vzestupu? Personalizace volebního chování v České republice. Sociologický časopis / Czech Sociological Review 53(2), 147-180, https://doi.org/10.13060 /00380288.2017.53.2.304.

Lipset, S. M., Rokkan, S. (1967): Party Systems and Voter Alignments. New York: Free Press.

MacAllister, I., Johnston, R., Pattie, C., Tunstall, H., Dorling, D., Rossiter, D. (2001): Class Dealignment and the Neighbourhood Effect: Miller Revisited. British Journal of Political Science 31(1), 41-59, https://doi.org/10.1017 /S0007123401000035.

Malcová, K. (2012): Lokální aspekt volební podpory kandidátů do Senátu Parlamentu ČR. Sociologický časopis / Czech Sociological Review 48(2), 283-313, https://doi.org/10.13060/00380288.2012.48.2.04.

Mikešová, R. (2019): Vliv lokálního prostředí na volební chování v Česku. Geografie 124(4), 411-432, https://doi .org/10.37040/geografie2019124040411.

Miller, W. L. (1977): Electoral Dynamics in Britain since 1918. London: Palgrave MacMillan.

Mudde, C., Kaltwasser, C. R. (2018): Studying Populism in Comparative Perspective: Reflections on the Contemporary and Future Research Agenda. Comparative Political Studies 51(13), 1667-1693, https://doi.org/10.1177/0010414018789490.

Musil, J., Müller, J. (2008): Vnitřní periferie v České republice jako mechanismus sociální exkluze. Sociologický časopis / Czech Sociological Review 44(2), 321-348, https://doi .org/10.13060/00380288.2008.44.2.05.

Novák, J., Netrdová, P. (2011): Prostorové vzorce sociálněekonomické diferenciace obcí v České republice. Sociologický časopis / Czech Sociological Review 47(4), 
717-744, https://doi.org/10.13060/00380288.2011 .47.4.05.

Panagopoulos, C., Leighley, J. E., Hamel, B. (2017): Are Voters Mobilized by a 'Friend-and-Neighbor' on the Ballot? Evidence from a Field Experiment. Political Behavior 39(4), 865-882, https://doi.org/10.1007 /s11109-016-9383-3.

Panagopoulos, C., Bailey, K. (2020): "Friends-and-Neighbors" Mobilization: A Field Experimental Replication and Extension. Journal of Experimental Political Science 7(1), 13-26, https://doi.org/10.1017/XPS.2019.1.

Pattie, C., Johnston, R. (2000): “People Who Talk Together Vote Together": An Exploration of Contextual Effects in Great Britain. Annals of the Association of American Geographers 90(1), 41-66, https://doi.org/10.1111 /0004-5608.00183.

Pickery, J. (2002): Contextual effects on the vote in Germany: A multilevel analysis. Discussion Papers. Berlin: WZB Social Science Center.

Put, G.-J., Maddens, B. (2015): The Effect of Municipality Size and Local Office on the Electoral Success of Belgian/ Flemish Election Candidates: A Multilevel Analysis. Government and Opposition 50(4), 607-628, https:// doi.org/10.1017/gov.2014.36.

Put, G.-J., Schoultz, A., Isotalo, V. (2020): Fighting over friends and neighbors: The effect of inter-candidate geographic distance on intra-party competition. Political Geography 81, 1-12, https://doi.org/10.1016/j.polgeo .2020 .102219 .

Put, G.-J. (2021): Is there a friends-and-neighbors effect for party leaders?. Electoral Studies 71,1-10, https://doi .org/10.1016/j.electstud.2021.102338.

Rice, T. W., Macht, A. A. (1987): The Hometown Advantage: Mobilization or Conversion?. Political Behavior 9(3), 257-262, https://doi.org/10.1007/BF00988615.

Roy, J., Alcantara, C. (2015): The Candidate Effect: Does the Local Candidate Matter? Journal of Elections, Public Opinion and Parties 25(2), 195-214, https://doi.org /10.1080/17457289.2014.925461.
Řeháková, B. (1999): Předčasné volby 1998: Volební chování různých skupin voličů. Sociologický časopis / Czech Sociological Review 35(3), 311-334, https://doi .org/10.13060/00380288.1999.35.3.06.

Sedláčková, M. (2012): Důvěra a demokracie. Přehled sociologických teorií důvěry od Tocquevilla po transformaci v postkomunistických zemích. Praha: Sociologické nakladatelství SLON.

Shin, M. E. (2001): The politicization of place in Italy. Political Geography 20(3), 331-352, https://doi .org/10.1016/S0962-6298(00)00067-6.

Schulte-Cloos, J., Bauer, P. C. (2021): Local Candidates, PlaceBased Identities, and Electoral Success. Political Behavior, https://doi.org/10.1007/s11109-021-09712-y.

Stephens, J. D. (1981): The Changing Swedish Electorate: Class Voting, Contextual Effects and Voter Volatility. Comparative Political Studies 14(2), 163-204, https:// doi.org/10.1177/001041408101400202.

Šimon, M. (2015): Measuring phantom borders: the case of Czech/Czechoslovakian electoral geography. Erdkunde 69(2), 139-150, https://doi.org/10.3112/erdkunde .2015 .02 .04 .

Tatalovich, R. (1975): "Friends and Neighbors" Voting: Mississippi, 1943-73. The Journal of Politics 37(3), 807-814, https://doi.org/10.2307 /2129327.

Taylor, P., Johnston, R. (1979): Geography of Elections. London: Penguin Books.

Voda, P., Pink, M. (2009): Kandidáti v poslaneckých volbách. Analýza preferenčního hlasování ve volbách do PS PČR v roce 2006. Středoevropské politické studie 11(2-3), 163-180.

Voda, P. (2010): Volební geografie ČR: Analýza volební podpory KDU-ČSL. Diploma thesis. Brno: Masaryk University, Faculty of Science.

Weng, L.-C. D. (2015): Contextual Effects on Individual Voting Behavior: The Case of Taiwan. Asian Journal of Political Science 23(3), 321-345, https://doi.org /10.1080/02185377.2015.1073602. 